\begin{tabular}{|c|c|}
\hline & Volume \& Issues Obtainable at The Women University Multan \\
Annals of Social Sciences and Perspective \\
ISSN: 2707-7063, Volume 2, No.2 December 2021
\end{tabular}

\title{
The Relationship between Mentoring Functions and Employee Performance: Mediating Effects of Protégé Relational Self-Efficacy
}

\author{
Muhammad Shaukat Malik', Muhammad Kashif Nawaz ${ }^{2}$
}

${ }^{1}$ Institute of Banking \& Finance, Bahauddin Zakariya University, Multan.

${ }^{2}$ Ph.D Scholar, Institute of Banking \& Finance, Bahauddin Zakariya University, Multan.

\section{ARTICLE DETAILS}

\section{History:}

Received:

Review:

Accepted:

August 16,2021

October 15,2021

October 15,2021

Available Online: November 02, 2021

Mentoring functions, Employee

Performance, Relational Self Efficacy.

\section{DOI:}

10.52700/assap.v2i2.106

\section{Keywords:}

\section{ABSTRACT}

Organizational scholars concurred that positive workplace relationships with others can help the employee to gain from these relationships but, they lack insights into how or why this occurs. Moreover, the relationship dynamics focus on what the relationships provide without considering how these relationships are initiated, builds and maintains. In the line with this, the current study aims to find the impact of mentoring functions (career, psychosocial, role modeling) and employee performance (career success, organization citizenship behavior, and job performance) via mediating effect of relational self-efficacy. For this purpose, the data were gathered from 310 branch banking employees of Pakistani conventional banks. PLS-SEM was used for data analysis. The results indicate that there is a direct relationship between mentoring functions and employee performance. Moreover, the finding also shows that employee relational self-efficacy mediates the relationship between mentoring functions and employee performance. Theoretical and practical implications are discussed along with suggestions for future research.

(C) 2021 The Authors, Published by WUM. This is an Open Access Article under the Creative Common Attribution Non Commercial 4.0

Corresponding author's email address: kashif347@gmail.com

\section{Introduction}

Employees entering or new in the organization proactively engaged in networking with others to seek guidance, help and advice from them. Prior literature highlights that individuals proactively in networking leads to positive career and work related outcomes (Ellis, Nifadkar, Bauer, \& Erdogan, 2017). Moreover, high quality workplace relationships can be the source of engagement, connection and vitality (Dutton \& Ragins, 2007; Kahn, 2007). Positive work relationships such as career advancement, task assistance, personal growth, emotional support, friendship, and the opportunity to give to others has been positively associated with 
employee performance like job and life satisfaction and positive emotions (Colbert, Bono, \& Purvanova, 2016). Workplace relationships refer to relationships in the context of a person's current place of work as well as relationships in that person's broader professional networks that may cross organizational or even industry boundaries.

However, prior literature lacks the evidence that protégé ability in developing successful relationships with others. Rochford, Bergeron, \& Clerkin, (2019) introduced the notion of relational self-efficacy that is individual belief in initiation, building and maintaining a meaningful relationship with others to get maximum gains from the relationship. An employee with more relational self-efficacy will build the relationship with seniors and acquire maximum benefits through these relationships in comparison to individuals who lack relational self-efficacy. Thus, individuals stand to gain or lose a lot depending on the extent to which they are utilizing their relational capacities. Therefore, helping individuals to builds their relational self-efficacy could be one of the ways that assist them to successful building the relationship with others for maximum gains from their relationships.

Based upon Bandura (1982) sources of self-efficacy are vicarious learning would occur through observing the types of relationships other people have with the person of interest and verbal persuasion involves the individual being persuaded by another individual (mentor) that they can complete the task successfully. Therefore, it is important to study the factors that enhance the relational self-efficacy among protégés. Relational self-efficacy can be derived through a combination of personal, behavioral, and environmental factors both within a person and between people participating in a given interaction. Mentoring could be an environmental factor that impacts the individual relational self-efficacy. Mentoring has long been recognized in developing the personal and career development of protégés. According to the current study, we seek to understand the individual's relational self-efficacy in successful initiation, building and retaining the relationship with others to get maximum benefits from these relationships such as career success, organization citizenship behavior and job performance.

Therefore, in light of the gap, in the present study, we proposed the mediation model between mentoring functions (career, psychosocial and role modeling) and employee performance (career success, organization citizenship behavior and job performance) based on relational self-efficacy theory to provide the empirical evidence from Pakistan.

\section{Literature Review}

The quality and quantity of relationships people have with their peers, supervisors, and broader networks impact numerous individual and organizational outcomes. The mentoring and social support literature present a starting point, emphasizing the gains from receipt of emotional and task related support and career development via positive relationships (Kram, 1985; Stroebe \& Stroebe, 1996). The relationship theory (Feeney \& Collins, 2014) put forward that these positive connections also assist individuals to hunt opportunities for development and growth. In the line with this theory, researcher's puts forward that positive workplace relationships might be the source of vitality, enrichment and learning that assist peoples, teams and organizations to thrive, grow and flourish (Ragins \& Dutton, 2007).

In a broader context of the workplace, relationships have significant altered the personal and professional lives of individuals. The employees have to blend what they do professionally and personally so that both might work. As boundaries between work and non-work identities 
become blurred (Ramarajan \& Reid, 2013), work relationships are not only sources of instrumental work relevant support (e.g., career advice and ask assistance); they may also be a source of resources with implications beyond the work domain, such as personal growth and friendship (Niven, Holman, \& Totterdell, 2012).

\subsection{Mentoring Functions}

A mentor is an experienced individual who provides career guidance and personal support to a less experienced individual (Kram, 1985). Kram (1983) outlined two traditional functions that mentors provide to the mentee in the average quality relationship: career and psychosocial. Earlier consist of sponsorship, exposure and visibility, coaching protection and challenging assignments while later contains role modeling, acceptance and confirmation, counseling, and friendship. Hence, traditional perspectives on mentoring relationship highlight what the mentor supply what receives by mentee; the model is an exchange based (Ragins \& Verbos, 2007). Prior studies also identified three overarching mentor functions: career, psychosocial, and role modeling (Scandura, 1992; Scandura \& Viator, 1994).

At the workplace, there are plenty of dyadic relationships exist, supervisor and subordinate, manager and employee, peer relationship but mentoring relationships are unique. First, mentors and mentees are not always belong to the same supervisor chain, and often they are even employed in a different organization (Ragins, 2012). Therefore, mentoring relationships are different from leader-member and supervisor-supervisee relationships (Godshalk \& Sosik, 2007) but managers and leaders can also be engaged in mentoring relationships (e.g., offering challenging tasks, coaching, friendship) to individuals with less experience. Fletcher and Ragins, (2007) stated that these mentoring episodes alone do not comprise a mentoring relationship. In addition, many leaders can also be mentors and mentoring support behaviors are distinctive from the support leaders provide (Ragins \& Kram 2007).

\subsection{Workplace Relational Self-efficacy}

Relational self-efficacy can be described as an individual's belief in initiation, development, and maintaining desired workplace relationships with others (Rochford, Bergeron, \& Clerkin, 2019). An individual with higher relational self-efficacy does not necessarily desire to maintain relationships with everyone rather its means that they believe in their ability to develop the desired relationship with others and it includes the peers, supervisor, subordinates and seniors from the same or outside the organization. While workplace relational selfefficacy can certainly be thought of in the context of friendships, in the professional domain, relationships serve many more functions than friendship (Colbert, Bono, Purvanova, 2016). Workplace relationship is a broader term that includes all types of work and professional relationships. Workplace relational self efficacy is different from non workplace relationships as it incorporates different risks, benefits, and types of relationships.

\subsection{Job Performance}

Job performance is a set of outcomes produced by a particular work, activity, or task in a particular time period (Bernardin, Hagan, Kane, \& Villanova, 1998). Another author Motowidlo (2003), job performance is a total expected value to the company of the discrete behavioral episodes that employees do at a particular time. It refers to the quality, effectiveness and efficiency of their work. Through these criteria, the organization can evaluate the individuals that how valuable the individual is for them. Further, it is also total 
output expected from an employee at a particular work. Moreover, task performance is the employee effectiveness through which they perform tasks that support the organization directly or indirectly (Borman and Motowidlo, 1997). Employee job performance is vital for gaining competitive advantage and organizational effectiveness.

\subsection{Organizational Citizenship Behavior}

Organizational citizenship behavior (OCB) is defined as the optional behavior of a person that is not directly or explicitly part of the formal duty of a person that enhances the organization's performance (Organ, 1988). OCB refers to the behavior that goes beyond the formal duty, which is directed towards teamwork in an organization for the attainment of organization goals (Somech \& Drach-Zahavy, 2000). In other words, OCB is a discretionary work related behavior that goes further than the stated duty that supports an individual psychological or social environment (Ersoy et al., 2015). OCB can lead towards the effectiveness of a firm via an individual's behavior. As job task is often supposed to require a combined effort rather than individual effort, OCB plays a significant role when job tasks involve collaboration and cooperation within teams and employees. When workers engaged in $\mathrm{OCB}$, the client might consider this as exceeding their expectations resultantly positive towards the company. OCB is defined based on target or direction of behavior that directly assist the worker and indirectly organization (Williams \& Anderson, 1991).

\subsection{Career Success}

Arthur et al. (2005) define career success as an achievement of work related performance at any specific point in an individual's work experience over time. It's categorized into objective and subjective terms. Most researchers argued that subjective career success (SCS) is distinctive from objective career success (OCS) (Arthur et al., 2005; Heslin 2005). SCS is measured by using self-referent criteria. It refers to the psychological perception of attainment of career related ambitions or subjective satisfaction with their career accomplishments (Heslin 2005). On the other hand, OCS is measured directly through some tangible elements such as salary increment, job status. It comprises of the number of promotions, salary packages and other related accomplishments whereas SCS is considered as workers' satisfaction with their career success (Callanan, 2003). SCS is perceived as indistinct and relies upon individuals' self referent whereas OCS is supported by landmarks that are readily compared with pears (Arthur et al., 2005).

According to Akkermans and Kubasch, (2017) is a leading research topic in main career journals. Few authors operationalized the OCS in objective terms (Van Dierendonck and Van der Gaast, 2013) and whereas SCS differently operationalized e.g. goal achievement in one's career (Creed and Hood, 2015), career satisfaction (Spurk, Abele, \& Volmer, 2015) and expectations of career success (Shoffner, Newsome, Barrio Minton, \& Wachter Morris, 2015).

\subsection{Mentoring Functions and Employee Performance}

The researcher has conducted several meta-analysis reviews on mentoring and its outcomes. Allen, Eby, Poteet, Lentz, \& Lima, (2004) concluded in their meta-analysis that individual with the mentoring relationship was more satisfied with their jobs, careers and more expected to attain career success than non mentored individuals. Underhill, (2006) stated that Moreover, informal mentoring significantly predicts career outcomes compared to formal 
mentoring. Protégés and Mentors' roles varied in mentoring relationships, but both attain several benefits and are more satisfied with mentoring relationships (Bozeman and Feeney, 2009). Further, Eby, Allen, Evans, Ng, \& DuBois, (2008) reviewed the quantitative studies published during (1985 to 2006) explore the youth, academic and workplace mentoring area to find the mentee outcomes from mentoring relationships. The finding indicates that mentoring relationship predicts several positive outcomes like behavioral, attitudinal, motivational, relational, health related and career outcomes. These outcomes comprise, for example, perceptions of career success (Allen, Lentz, \& Day, 2006), job satisfaction, organizational commitment (Ghosh \& Reio, 2013), affective well-being (Chun et al., 2012), and several authors contend that mentoring relationships have a significant impact on protégé personal and career development (Eby, Allen, Evans, Ng, \& DuBois, 2008; Tolar, 2012).

Prior literature highlights that mentors provide various functions (career, psychosocial and role modeling) which help protégé in development in personal and professional domains (Eby, Allen, Evans, Ng, \& DuBois, 2008; Tolar, 2012). A meta-analysis conducted by (Allen, Eby, Poteet, Lentz, \& Lima, 2004) suggests that individual with the mentoring relationship was more satisfied with their jobs, and more expected to attain career success. Further, mentoring relationship predicts several positive outcomes like behavioral, attitudinal, motivational, relational, health related and career related outcomes (Eby, Allen, Evans, Ng, \& DuBois, 2008). Ghosh and Reio (2013) on mentoring functions were positively linked with career related outcomes for mentor: organization commitment, job satisfaction, career success, performance, and intention to quit. Moreover, Lee, \& Lee, (2018) investigate that coaching/mentoring is from the perspective of organizational factor is found that it's significantly predicts job performance. Ouerdian, \& Mansour, (2019) on a sample of Tunisian bankers found that receipt of mentoring support is significantly related with career success.

\subsection{Mediating of Relational Self-efficacy}

Bandura (2006) is explicit in his belief that self-efficacy is not a trait and should not be measured as such. Rather, Bandura argues that measures of self-efficacy should relate to either the task or specific domain of functioning. Relationship self-efficacy is related to the specific domain of initiation, building and maintaining the relationship with others.

Bandura highlights four sources of self-efficacy: (1) enactive mastery; (2) vicarious experiences; (3) verbal persuasion; and (4) physiological state. Enactive mastering refers to the person's experience with the task at hand. Bandura argues that experiences of enactive mastery are the most persuasive for increasing self-efficacy (Bandura, 1982). Vicarious experience refers to an individual observing a person they consider to be similar to themselves perform the task (or a similar task) successfully. Vicarious learning would occur through observing the types of relationships other people have with the person of interest. A person's workplace relational self efficacy would be influenced by vicarious learning as watching closely the relational role in the past. Verbal persuasion involves the person being persuaded by another person that they have the ability to complete the task effectively. Bandura notes that verbal persuasion is most effective when the individual considers "the heightened appraisal is within realistic bounds (1982: 127). Verbal persuasion might influence a person's workplace relational self-efficacy through questions such as have I have received positive feedback regarding my ability in the relational role. Finally, when forming self-efficacy beliefs, individuals take cues from their physiological state. 
Son (2016) shows that the finding among 131 matched mentoring dyadic relationships in three diverse organizations indicates that the mentee received support from the mentor is significantly associated with networking and socialization of mentee. Consistent with Bandura's conceptualization, workplace relational self-efficacy is conceptualized as a statelike variable. That is, it is expected that a person's workplace relational self-efficacy will change across time, contexts, and types of relationships. Compared to information and feedback seeking, relationship building behaviors, such as getting to know the mentor more and spending time to get along with the mentor, are more likely to build friendly (rather than instrumental) connections with the mentor, which can help mentors to be more willing to share information and help newcomers with their socialization.

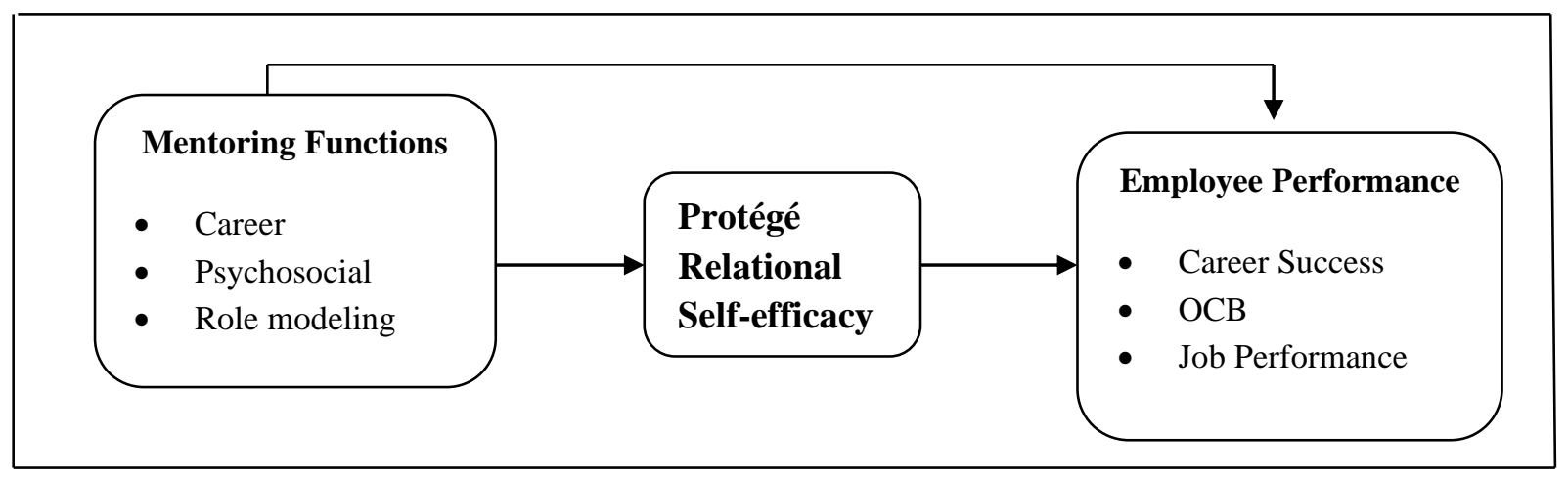

Figure1: Theoretical Model

\section{Hypothesis}

From the above following, the hypothesis has been proposed.

H1: There is a positive and significant relationship between mentoring functions and protégé relational self-efficacy.

H2: There is a positive and significant relationship between mentoring functions and Employee Performance.

H3: There is a positive and significant relationship between protégé relational self-efficacy and Employee Performance.

H4: Protégé relational self-efficacy mediates the relationship between mentoring functions and employee performance.

\section{Research Methodology}

\subsection{Populations and Sampling}

The population of the current study was staff working in branches of Pakistan conventional banks. A self-administered questionnaire was employed to collect the responses from 310 branch banking employees working in conventional banks of Pakistan. A simple random sampling technique was used for data collection. PLS-SEM was used for data analysis.

\subsection{Measures}

Variable studied in the current study was adopted from earlier studies, more specifically. Mentoring Functions Questionnaire (MFQ-9), a 9-items short form scale developed by Castro $\&$ Williams, (2004) was used. To measure relational self-efficacy 8 items were developed by Rochford et. al., (2019). To measure career success 8-items scale developed by Greenhaus et 
al. (1990) and Nabi (1999) was used. Eight items scales developed by Lee and Allen (2002) were used to measure organization citizenship behavior. To measure self reported job performance 4 items scale was developed by Bright, (2007). A five point Likert scale was used to gather data.

\section{Data Analysis}

PLS-SEM (latest version 3.2.6) second generation multivariate was used for data analysis (Ringle et al., 2015). PLS-SEM is appropriate for theory building and also for prediction (Hair et al., 2016). In our study all constructs were reflective. Firstly, the reliability and validity of data were validated through a measurement model and in the next step structural model was used for estimation of the path coefficient and the significance.

Reliability and validity of the reflective measurement model were tested via the following criteria, indicators reliability, internal consistency reliability, convergent validity, and discriminant validity. The factor loading of the individual items should be assessed by looking into the outer loading of each studied variable. The researcher provides a standardized value for retaining the individual's items valuing higher than 0.70 . In the current studies, all outer loading of individual items was greater than 0.70 which indicates that all measures were reliable Table I. Secondly, to test the internal consistency the Cronbach's alpha value is used. The authors argue that the acceptable range of Cronbach's alpha must be higher than 0.70 and in our studies values of Cronbach's alpha in the table, I was ranged from 0.748 to 0.906 , and the present study has successfully met the criterion of internal consistency.

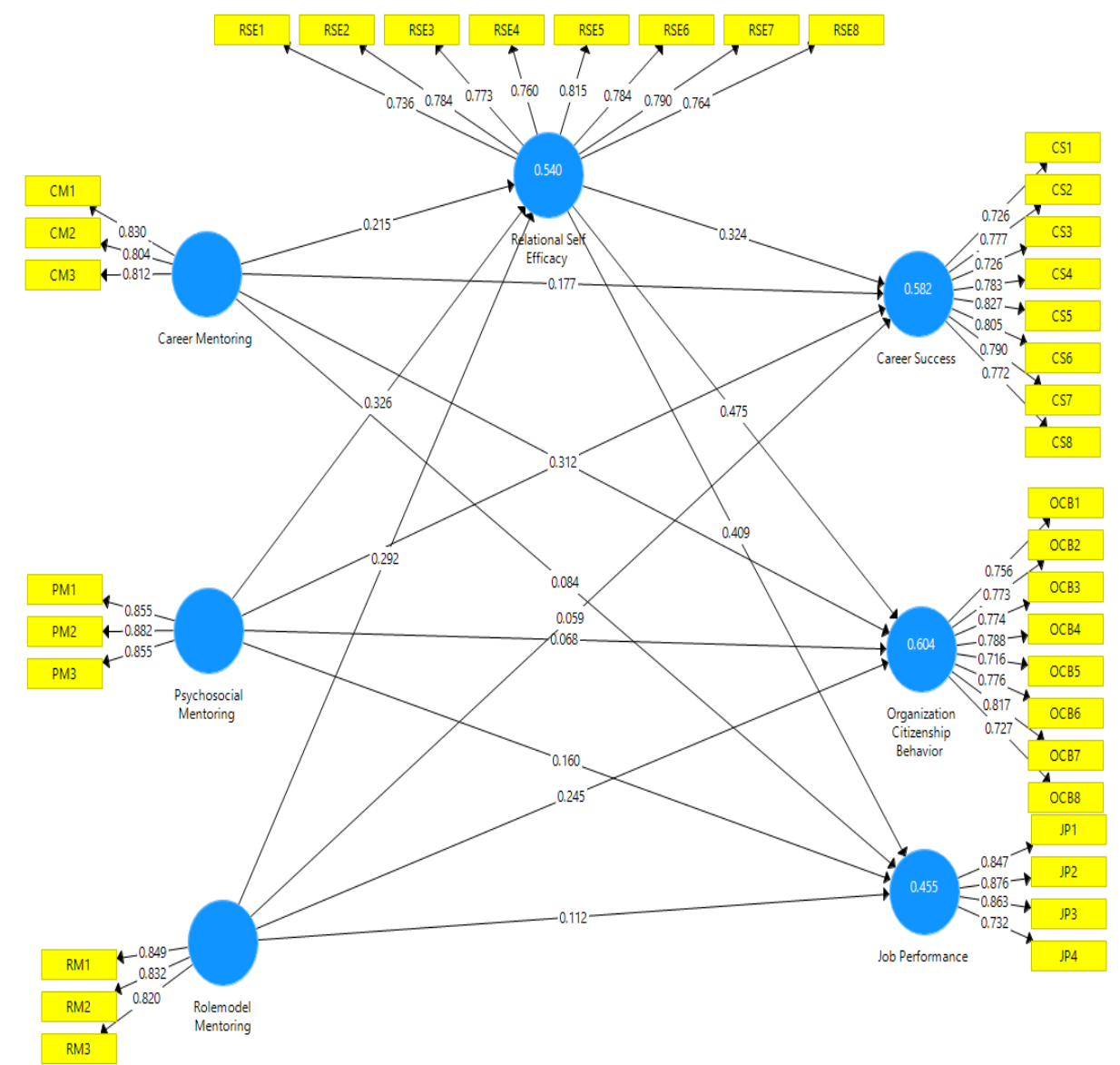

Figure 2: Measurement Model 
Further, the composite reliability coefficient is used to assess the internal consistency reliability of the measures. The authors suggested the standardized range for composite reliability coefficient must be 0.7 or above. In the current study, the composite reliability (CR) coefficient is arranged from 0.856 to 0.924 showing in table I the adequate internal consistency of studied variables.

Table I: Reflective Model assessment: Indicators reliability, internal consistency, Convergent Validity

\begin{tabular}{|c|c|c|c|c|c|}
\hline & Items & Loading & AVE & Cronbach Alfa & $\begin{array}{l}\text { Composite } \\
\text { Reliability }\end{array}$ \\
\hline \multirow{3}{*}{ Career Mentoring } & CM1 & 0.830 & 0.665 & 0.748 & 0.856 \\
\hline & CM2 & 0.804 & & & \\
\hline & CM3 & 0.812 & & & \\
\hline \multirow[t]{8}{*}{ Career Success } & CS1 & 0.726 & 0.603 & 0.906 & 0.924 \\
\hline & $\mathrm{CS} 2$ & 0.777 & & & \\
\hline & CS3 & 0.726 & & & \\
\hline & CS4 & 0.783 & & & \\
\hline & CS5 & 0.827 & & & \\
\hline & CS6 & 0.805 & & & \\
\hline & CS7 & 0.790 & & & \\
\hline & CS8 & 0.772 & & & \\
\hline \multirow[t]{4}{*}{ Job Performance } & JP1 & 0.847 & 0.692 & 0.850 & 0.899 \\
\hline & JP2 & 0.876 & & & \\
\hline & JP3 & 0.863 & & & \\
\hline & JP4 & 0.732 & & & \\
\hline \multirow[t]{8}{*}{$\begin{array}{l}\text { Organization citizenship } \\
\text { behavior }\end{array}$} & OCB1 & 0.756 & 0.588 & 0.899 & 0.919 \\
\hline & OCB2 & 0.773 & & & \\
\hline & OCB3 & 0.774 & & & \\
\hline & OCB4 & 0.788 & & & \\
\hline & OCB5 & 0.716 & & & \\
\hline & OCB6 & 0.776 & & & \\
\hline & OCB7 & 0.817 & & & \\
\hline & OCB8 & 0.727 & & & \\
\hline \multirow[t]{3}{*}{ Psychosocial Mentoring } & PM1 & 0.855 & 0.747 & 0.830 & 0.898 \\
\hline & PM2 & 0.882 & & & \\
\hline & PM3 & 0.855 & & & \\
\hline \multirow[t]{3}{*}{ Role modeling Mentoring } & RMM1 & 0.849 & 0.695 & 0.781 & 0.872 \\
\hline & RMM2 & 0.832 & & & \\
\hline & RMM3 & 0.820 & & & \\
\hline \multirow[t]{8}{*}{ Relational Self-efficacy } & RSE1 & 0.736 & 0.602 & 0.906 & 0.924 \\
\hline & RSE2 & 0.784 & & & \\
\hline & RSE3 & 0.773 & & & \\
\hline & RSE4 & 0.760 & & & \\
\hline & RSE5 & 0.815 & & & \\
\hline & RSE6 & 0.784 & & & \\
\hline & RSE7 & 0.790 & & & \\
\hline & RSE8 & 0.764 & & & \\
\hline
\end{tabular}

Fornell and Larcker (1981) proposed the average variance extracted (AVE) for convergent validity. The factor loading and AVE of all latent variables were used to establish the 
convergent validity. Convergent validity is the degree to which a measure positively correlates with others measure of variables (Hair et al., 2014, p. 102). The standardized value of AVE must be greater than 0.50 (Hair et al., 2014). Results of current studies show that all AVE values are greater than the acceptable range hence; it concludes the convergent validity is established in the present study.

In the next step of the measurement model, construct validity was examined which states that each latent variable must be distinct from other constructs of study (Bagozzi et al., 1991). It was evaluated by using Fornell-Larcker test (Fornell and Larcker's, 1981; Hair et al. 2014) and heterotrait-monotrait (HTMT) ratio (Henseler et al., 2015) and through cross loadings.

Discriminant validity was examined via Fornell-Larcker test (Fornell and Larcker's, 1981), according to this criterion the square root of AVE value must be higher than the correlations among all studied variables. Results in Table II indicate that the square root of the AVE value was higher than correlations among all studied variables, therefore; discriminant validity was established in our study.

Table 2: Discriminant Validity based on Fornell-Larcker Criterion

\begin{tabular}{lccccccc}
\hline & $\mathbf{1}$ & $\mathbf{2}$ & $\mathbf{3}$ & $\mathbf{4}$ & $\mathbf{5}$ & $\mathbf{6}$ & $\mathbf{7}$ \\
\hline Career Mentoring & 0.815 & & & & & & \\
\hline Career Success & 0.630 & 0.776 & & & & & \\
\hline Job Performance & 0.517 & 0.575 & 0.832 & & & & \\
\hline Organization Citizenship Behavior & 0.583 & 0.641 & 0.759 & 0.767 & & & \\
\hline Psychosocial Mentoring & 0.693 & 0.691 & 0.567 & 0.614 & 0.864 & & \\
\hline Relational Self Efficacy & 0.620 & 0.681 & 0.640 & 0.735 & 0.671 & 0.776 & \\
\hline Rolemodel Mentoring & 0.611 & 0.584 & 0.533 & 0.651 & 0.669 & 0.642 & 0.834 \\
\hline
\end{tabular}

Note: AVE values are shown in diagonals, and off-diagonals shows the correlations

HTMT is used for the estimation of correlation between variables and if HTMT value is less than 1 means that constructs are different from other studied constructs (Haider et al., 2018). Results in table III of the current study show that all values are less than 0.90, hence; the discriminant validity is proved in our study.

Table 3: Discriminant Validity based on HTMT Criterion

\begin{tabular}{llllllll}
\hline & 1 & 2 & 3 & 4 & 5 & 6 & 7 \\
\hline Career Mentoring & & & & & & & \\
\hline Career Success & 0.763 & & & & & \\
\hline Job Performance & 0.634 & 0.640 & & & & \\
\hline Organization Citizenship Behavior & 0.705 & 0.704 & 0.867 & & & \\
\hline Psychosocial Mentoring & 0.879 & 0.793 & 0.668 & 0.707 & & \\
\hline Relational Self Efficacy & 0.749 & 0.743 & 0.721 & 0.808 & 0.769 & \\
\hline Rolemodel Mentoring & 0.796 & 0.690 & 0.650 & 0.776 & 0.831 & 0.758 \\
\hline
\end{tabular}

Another criterion is used for determining the discriminant validity. Loading of items must greater than cross-loading of items (Götz et al. 2010). In our study, all loading is greater than the cross-loading as shown in table IV. Therefore, it is concluded that all measures studies in the current study have an adequate level of discriminant validity. 
Table 4: Cross loading

\begin{tabular}{|c|c|c|c|c|c|c|c|}
\hline & $\begin{array}{l}\text { Career } \\
\text { Mentoring }\end{array}$ & $\begin{array}{l}\text { Career } \\
\text { Success }\end{array}$ & $\begin{array}{l}\text { Job } \\
\text { Performance }\end{array}$ & $\begin{array}{l}\text { Organization } \\
\text { Citizenship } \\
\text { Behavior } \\
\end{array}$ & $\begin{array}{l}\text { Psychosocial } \\
\text { Mentoring }\end{array}$ & $\begin{array}{l}\text { Relational } \\
\text { Self } \\
\text { Efficacy } \\
\end{array}$ & $\begin{array}{l}\text { Rolemodel } \\
\text { Mentoring }\end{array}$ \\
\hline CM1 & $\mathbf{0 . 8 3 0}$ & 0.503 & 0.438 & 0.491 & 0.577 & 0.537 & 0.510 \\
\hline CM2 & 0.804 & 0.519 & 0.334 & 0.408 & 0.565 & 0.490 & 0.435 \\
\hline CM3 & 0.812 & 0.519 & 0.482 & 0.519 & 0.554 & 0.488 & 0.543 \\
\hline CS1 & 0.521 & 0.726 & 0.464 & 0.527 & 0.590 & 0.567 & 0.515 \\
\hline $\mathrm{CS} 2$ & 0.474 & 0.777 & 0.468 & 0.555 & 0.547 & 0.619 & 0.448 \\
\hline $\mathrm{CS} 3$ & 0.422 & 0.726 & 0.390 & 0.418 & 0.539 & 0.473 & 0.409 \\
\hline $\mathrm{CS} 4$ & 0.441 & 0.783 & 0.438 & 0.419 & 0.562 & 0.505 & 0.419 \\
\hline CS5 & 0.463 & 0.827 & 0.440 & 0.486 & 0.475 & 0.487 & 0.426 \\
\hline CS6 & 0.539 & 0.805 & 0.383 & 0.444 & 0.509 & 0.464 & 0.406 \\
\hline CS7 & 0.512 & 0.790 & 0.454 & 0.554 & 0.504 & 0.520 & 0.463 \\
\hline CS8 & 0.524 & 0.772 & 0.509 & 0.549 & 0.547 & 0.562 & 0.515 \\
\hline JP1 & 0.479 & 0.543 & 0.847 & 0.637 & 0.510 & 0.562 & 0.463 \\
\hline JP2 & 0.491 & 0.558 & 0.876 & 0.664 & 0.541 & 0.590 & 0.459 \\
\hline JP3 & 0.411 & 0.452 & 0.863 & 0.655 & 0.459 & 0.518 & 0.493 \\
\hline JP4 & 0.314 & 0.324 & 0.732 & 0.566 & 0.354 & 0.444 & 0.343 \\
\hline OCB1 & 0.396 & 0.451 & 0.618 & 0.756 & 0.429 & 0.544 & 0.542 \\
\hline OCB2 & 0.462 & 0.477 & 0.630 & 0.773 & 0.444 & 0.564 & 0.463 \\
\hline OCB3 & 0.387 & 0.442 & 0.580 & 0.774 & 0.369 & 0.529 & 0.508 \\
\hline OCB4 & 0.401 & 0.493 & 0.664 & 0.788 & 0.425 & 0.576 & 0.496 \\
\hline OCB5 & 0.413 & 0.463 & 0.444 & 0.716 & 0.467 & 0.501 & 0.465 \\
\hline OCB6 & 0.513 & 0.512 & 0.543 & 0.776 & 0.523 & 0.557 & 0.486 \\
\hline OCB7 & 0.507 & 0.545 & 0.564 & 0.817 & 0.570 & 0.616 & 0.544 \\
\hline OCB8 & 0.482 & 0.533 & 0.607 & 0.727 & 0.520 & 0.605 & 0.487 \\
\hline PM1 & 0.568 & 0.577 & 0.522 & 0.507 & 0.855 & 0.555 & 0.559 \\
\hline PM2 & 0.637 & 0.638 & 0.480 & 0.549 & 0.882 & 0.580 & 0.588 \\
\hline PM3 & 0.591 & 0.576 & 0.470 & 0.535 & 0.855 & 0.603 & 0.587 \\
\hline RMM1 & 0.494 & 0.501 & 0.444 & 0.578 & 0.544 & 0.533 & 0.849 \\
\hline RMM2 & 0.526 & 0.484 & 0.412 & 0.537 & 0.563 & 0.548 & $\mathbf{0 . 8 3 2}$ \\
\hline RMM3 & 0.510 & 0.474 & 0.476 & 0.513 & 0.567 & 0.524 & $\begin{array}{l}0.820 \\
\end{array}$ \\
\hline RSE1 & 0.425 & 0.495 & 0.558 & 0.556 & 0.510 & 0.736 & 0.483 \\
\hline RSE2 & 0.496 & 0.605 & 0.530 & 0.642 & 0.559 & 0.784 & 0.546 \\
\hline RSE3 & 0.531 & 0.553 & 0.543 & 0.596 & 0.608 & 0.773 & 0.574 \\
\hline RSE4 & 0.499 & 0.497 & 0.452 & 0.567 & 0.501 & 0.760 & 0.433 \\
\hline RSE5 & 0.513 & 0.580 & 0.446 & 0.590 & 0.502 & 0.815 & 0.545 \\
\hline RSE6 & 0.474 & 0.493 & 0.493 & 0.528 & 0.467 & 0.784 & 0.427 \\
\hline RSE7 & 0.482 & 0.509 & 0.538 & 0.579 & 0.544 & 0.790 & 0.507 \\
\hline RSE8 & 0.411 & 0.471 & 0.389 & 0.478 & 0.447 & 0.764 & 0.443 \\
\hline
\end{tabular}

In the structural model, firstly, the collinearity issue was assessed in structural model evaluation. Collinearity means a high correlation between studied constructs (Hair et al., 2014). As a standard criterion to avoid collinearity, the value of variance inflation factor (VIF) value must be less than 5. In our study results reveals that VIF values were ranged from 1.958 to 2.593 , which indicates there is no collinearity issue in our data.

Secondly, path-coefficients of hypothesized relationship were calculated through the PLS algorithm, and significance was obtained by applying bootstrap standard error. A t-value is higher than $1.96(\mathrm{p}<0.05)$ indicates that the relationship is significant. In the next step, the coefficient of determination $\left(\mathrm{R}^{2}\right)$ was obtained. Table $\mathrm{V}$ shows the values of $\mathrm{R}^{2}$ indicating the 
level of variance explained by the exogenous constructs. As such, $\mathrm{R}^{2}$ values of $0.25,0.50$, and 0.75 are interpreted as weak, moderate and substantial respectively (Hair et al. 2014). More specifically, mentoring functions explained the level of variance in relational selfefficacy, career success and organizational citizenship behavior is substantial and moderate in job performance.

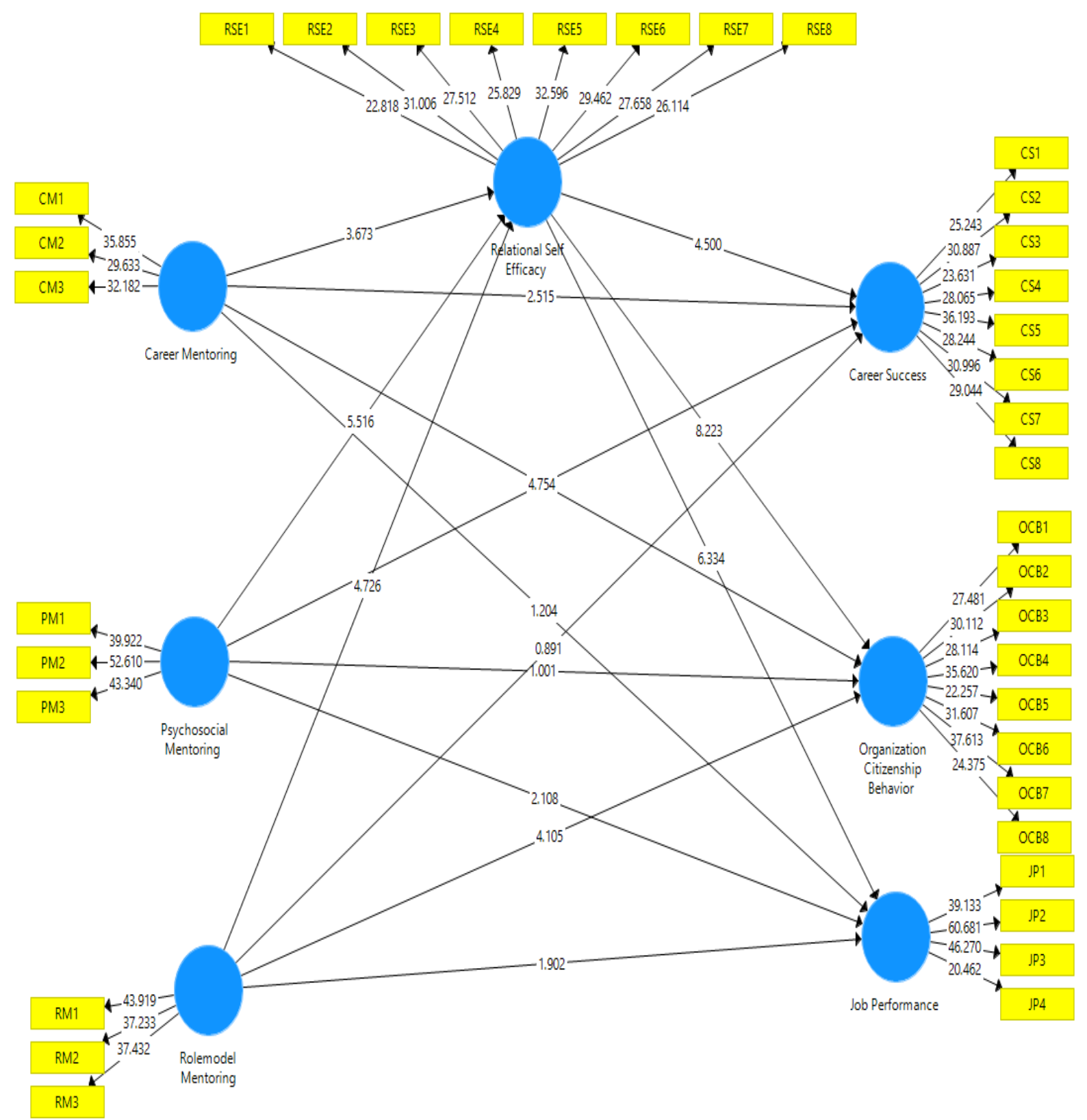

Figure 3: Structural Model

Table 5: Summary of Structural Model Assessment

\begin{tabular}{|c|c|c|c|c|}
\hline & $\mathrm{R}^{2}$ & T value & $P$ value & Assessment \\
\hline Career Success & 0.582 & 14.291 & 0.000 & Substantial \\
\hline Job Performance & 0.455 & 10.386 & 0.000 & Moderate \\
\hline Organization Citizenship Behavior & 0.604 & 14.633 & 0.000 & Substantial \\
\hline Relational Self Efficacy & 0.540 & 12.645 & 0.000 & Substantial \\
\hline
\end{tabular}


The relationship between mentoring functions (career, psychosocial, role modeling) is positively linked with employee performance (career success, organizations citizenship behavior, job performance) as shown in table 6 .

For mediation analysis we used the model proposed by Hair et al., (2017) relational self efficacy complementary mediation mediates the relationship between mentoring functions and employee outcomes (Job performance, organization citizenship behavior, career success). The finding shows that relational self-efficacy mediates the relationship between mentoring functions and employees outcomes.

Table 6: Hypothesis Testing

\begin{tabular}{lccccccc}
\hline Hypotheses & $\boldsymbol{\beta}$ & $\begin{array}{l}\text { S. } \\
\text { error }\end{array}$ & $\begin{array}{l}\text { t- } \\
\text { value }\end{array}$ & $\begin{array}{l}\text { Palue } \\
\text { val }\end{array}$ & Decisions & \multicolumn{2}{c}{ Confidence Interval } \\
\cline { 6 - 8 } CM-> CS & 0.246 & 0.073 & 3.385 & 0.001 & Supported & 0.105 & $\mathbf{9 7 . 5 0 \%}$ \\
\hline CM ->JP & 0.172 & 0.074 & 2.310 & 0.021 & Supported & 0.038 & 0.390 \\
\hline CM ->OCB & 0.194 & 0.060 & 3.238 & 0.001 & Supported & 0.089 & 0.321 \\
\hline CM -> RSE & 0.215 & 0.059 & 3.665 & 0.000 & Supported & 0.106 & 0.335 \\
\hline PM ->CS & 0.418 & 0.059 & 7.069 & 0.000 & Supported & 0.298 & 0.527 \\
\hline PM ->JP & 0.294 & 0.072 & 4.092 & 0.000 & Supported & 0.148 & 0.427 \\
\hline PM ->OCB & 0.223 & 0.066 & 3.381 & 0.001 & Supported & 0.091 & 0.346 \\
\hline PM -> RSE & 0.326 & 0.059 & 5.520 & 0.000 & Supported & 0.212 & 0.436 \\
\hline RSE ->CS & 0.324 & 0.078 & 4.128 & 0.000 & Supported & 0.181 & 0.487 \\
\hline RSE->JP & 0.409 & 0.066 & 6.236 & 0.000 & Supported & 0.273 & 0.525 \\
\hline RSE ->OCB & 0.475 & 0.055 & 8.575 & 0.000 & Supported & 0.372 & 0.579 \\
\hline RM ->CS & 0.153 & 0.065 & 2.345 & 0.019 & Supported & 0.020 & 0.287 \\
\hline RM ->JP & 0.231 & 0.063 & 3.646 & 0.000 & Supported & 0.100 & 0.343 \\
\hline RM ->OCB & 0.383 & 0.061 & 6.276 & 0.000 & Supported & 0.253 & 0.487 \\
\hline RM -> RSE & 0.292 & 0.064 & 4.584 & 0.000 & Supported & 0.166 & 0.405 \\
\hline CM->CSE->CS & 0.070 & 0.026 & 2.633 & 0.009 & Supported & 0.028 & 0.131 \\
\hline CM->CSE->JP & 0.088 & 0.026 & 3.318 & 0.001 & Supported & 0.040 & 0.142 \\
\hline CM->CSE>OCB & 0.102 & 0.029 & 3.551 & 0.000 & Supported & 0.049 & 0.161 \\
\hline PM->CSE->CS & 0.106 & 0.032 & 3.275 & 0.001 & Supported & 0.050 & 0.177 \\
\hline PM->CSE->JP & 0.133 & 0.033 & 4.104 & 0.000 & Supported & 0.073 & 0.195 \\
\hline PM->CSE>OCB & 0.155 & 0.033 & 4.639 & 0.000 & Supported & 0.096 & 0.221 \\
\hline RM->CSE->CS & 0.095 & 0.030 & 3.121 & 0.002 & Supported & 0.044 & 0.161 \\
\hline RM->CSE->JP & 0.119 & 0.033 & 3.645 & 0.000 & Supported & 0.059 & 0.180 \\
\hline RM->CSE>OCB & 0.139 & 0.036 & 3.888 & 0.000 & Supported & 0.074 & 0.211 \\
\hline & & & & & & & \\
\hline & & & & & & & \\
\hline
\end{tabular}


Table 7: Effect Size $\mathbf{f}^{2}$

\begin{tabular}{|c|c|c|}
\hline Hypothesis & 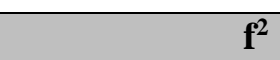 & Effect Size \\
\hline $\mathrm{CM}->\mathrm{CS}$ & 0.034 & $\mathrm{~S}$ \\
\hline $\mathrm{CM}->\mathrm{JP}$ & 0.006 & $S$ \\
\hline $\mathrm{CM}->\mathrm{OCB}$ & 0.010 & $S$ \\
\hline $\mathrm{CM}$-> RSE & 0.048 & $S$ \\
\hline $\mathrm{PM}->\mathrm{CS}$ & 0.090 & S \\
\hline PM ->JP & 0.018 & $\mathrm{~S}$ \\
\hline PM ->OCB & 0.004 & $S$ \\
\hline PM -> RSE & 0.098 & $\mathrm{~S}$ \\
\hline RSE ->CS & 0.116 & $\mathrm{M}$ \\
\hline RSE->JP & 0.141 & $S$ \\
\hline RSE ->OCB & 0.262 & $\mathrm{M}$ \\
\hline RM ->CS & 0.004 & $\mathrm{~S}$ \\
\hline RM ->JP & 0.011 & $\mathrm{~S}$ \\
\hline $\mathrm{RM}->\mathrm{OCB}$ & 0.070 & $\mathrm{~S}$ \\
\hline RM -> RSE & 0.095 & $\mathrm{~S}$ \\
\hline
\end{tabular}

For significant path coefficients, it is critical to examine the effect size $\left(f^{2}\right)$ of every exogenous variable on an endogenous variable (Hair et al. 2014). Effect size $\left(f^{2}\right)$ is used to measure the changes in the magnitude of $\mathrm{R}^{2}$ while omitting specific exogenous variables from the model. Moreover, values of $\mathrm{f}^{2} 0.02,0.15$ and 0.35 are believed as small (S), medium (M) and large (L) sizes respectively. The results of our study in table VII indicate that all values of $\mathrm{f}^{2}$ are small.

Table 8: Predictive Relevance $\mathbf{Q}^{2}$

\begin{tabular}{lrrr} 
Total & \multicolumn{1}{l}{ SSO } & \multicolumn{1}{l}{ SSE } & Q $^{\mathbf{2}}(=\mathbf{1 - S S E} / \mathbf{S S O})$ \\
\hline Career Success & $2,688.000$ & $1,798.541$ & $0.331(\mathrm{M})$ \\
\hline Job Performance & $1,344.000$ & 939.649 & $0.301(\mathrm{M})$ \\
\hline Organization Citizenship Behavior & $2,688.000$ & $1,779.109$ & $0.338(\mathrm{M})$ \\
\hline Relational Self Efficacy & $2,688.000$ & $1,855.080$ & $0.310(\mathrm{M})$ \\
\hline
\end{tabular}

Furthermore, to examine the quality of the model, predictive relevance $\mathrm{Q}^{2}$ must be measured (Hair et al., 2014). Stone-Geisser's $Q^{2}$ value can be used (Geisser 1974; Stone 1976). The value of $\mathrm{Q}^{2}$ is predicted by the average redundancy index of the endogenous latent variables (Hair et al. 2014). Further, values $\mathrm{f}^{2} 0.02,0.15$ and 0.35 are considered small (S), medium (M) and large (L) sizes respectively.

\section{Results and Discussion}

Relationships at the workplace might be the most meaningful relationships for the protégé. Such relationships offer work related resources such as emotional support, task assistance, and career advancement that are consistent with relationship theory (Feeney \& Collins, 2014; Kahn, 2007; Ragins \& Dutton, 2007). Positive relationships lead to personal growth, friendship and offer opportunities to give to others. For building a meaningful work relationship, individual relational self-efficacy is critical to initiate build and maintain relationships with others. 
Firstly, the present study intended to find the relationship between mentoring functions and employee performance. The findings of the present study show that there is a direct and significant relationship between mentoring functions and employee performance (career success, job performance, and OCB). These findings are consistent with the prior studies (Malik and Nawaz, (2020). We argued that protégé who can get more mentor support are better able to get succeed in their career and perform task in a better way.

Secondly, our aim was to find the impact of mentoring functions on employee relational selfefficacy. Finding of current study shows that there is a significant and positive relationship between mentoring functions and relational self-efficacy. We argued that mentors help to build efficacy via vicarious learning and verbal persuasions. Further, we argued that mentoring support might be viewed as a resource reservoir, and mentee might get various resources via mentoring relationships and ultimately builds employees resilience. Finally, the current study also investigates the mediating role of employee relational self-efficacy between mentoring functions and employee performance. Results also show that relational self-efficacy mediates the proposed relationships.

The findings prove the validity of relational self-efficacy in the Pakistani banking sector. According to relational self-efficacy, the individual belief in initiating builds and maintains meaningful relationships with others. Mentoring is a pivotal resource to build efficacious in employees and resultantly, employees with more relational self-efficacy will be better able to get benefits such as career success, job performance and OCB. The finding of the present study endorsed the relational self-efficacy theory perspective that provides that successful building the resource such as relational self-efficacy from mentor support will ultimately lead to employee Performance.

\section{Limitation and Future Recommendations}

In the present study, the traditional mentoring functions are discussed whereas in future study relational mentoring functions may also include investigating the relationship on employee outcomes. In a future study, such a relationship with building the protégé sustainable career might be included. The current study investigates the mediating role of relational selfefficacy, in the future, these might include career adaptability, career resilience. Moreover, the current study is cross sectional study; in the future longitudinal study might be conducted to investigate the impact of the particular mentoring program.

\section{Conclusion}

In the present study, mentoring functions studied as a predictor of relational self-efficacy and employee performance (career success, OCB, and job performance) provide empirical evidence from the Pakistani banking sector. This study provides the first empirical evidence that links between mentoring functions and employee performance through the mediation of relational self-efficacy. Moreover, the results highlight that employees who are more in receipt of mentoring support can build relational self-efficacy which resultantly helps them to initiate, build and maintain meaningful links within the organization and also from outside the boundaries of current employers. Such meaningful relations will help protégés in their career within the same organization and also in the industry. 


\section{References}

Akkermans, J., \& Kubasch, S. (2017). Trending topics in careers: A review and future research agenda. Career Development International, 22(6), 586-627.

Allen, T. D., Eby, L. T., Poteet, M. L., Lentz, E., \& Lima, L. (2004). Career benefits associated with mentoring for protégés: A meta-analysis. Journal of applied psychology, 89(1), 127.

Allen, T. D., Lentz, E., \& Day, R. (2006). Career success outcomes associated with mentoring others: A comparison of mentors and nonmentors. Journal of Career Development, 32(3), 272-285.

Arthur, M. B., Khapova, S. N., \& Wilderom, C. P. (2005). Career success in a boundaryless career world. Journal of Organizational Behavior: The International Journal of Industrial, Occupational and Organizational Psychology and Behavior, 26(2), 177202.

Bagozzi, R. P., Yi, Y., \& Phillips, L. W. (1991). Assessing construct validity in organizational research. Administrative science quarterly, 421-458.

Bandura, A. (1982). The assessment and predictive generality of self-percepts of efficacy. Journal of behavior therapy and experimental psychiatry, 13(3), 195-199.

Bandura, A. (2006). Toward a psychology of human agency. Perspectives on psychological science, 1(2), 164-180.

Bernardin, H. J., Hagan, C. M., Kane, J. S., \& Villanova, P. (1998). Performance Appraisal: State of the Art in Practice.

Borman, W. C., \& Motowidlo, S. J. (1997). Introduction: Organizational Citizenship Behavior and Contextual Performance.

Bozeman, B., \& Feeney, M. K. (2009). Public management mentoring: What affects outcomes?. Journal of Public Administration Research and Theory, 19(2), 427-452.

Bright, L. (2007). Does person-organization fit mediate the relationship between public service motivation and the job performance of public employees?. Review of public personnel administration, 27(4), 361-379.

Callanan, G. A. (2003). What price career success?. Career Development International.

Castro, S. L., \& Williams, E. A. (2004). Validity of Scandura and Ragins'(1993) multidimensional mentoring measure: An evaluation and refinement.

Chun, J. U., Sosik, J. J., \& Yun, N. Y. (2012). A longitudinal study of mentor and protégé outcomes in formal mentoring relationships. Journal of Organizational Behavior, 33(8), 1071-1094.

Colbert, A. E., Bono, J. E., \& Purvanova, R. K. (2016). Flourishing via workplace relationships: Moving beyond instrumental support. Academy of Management Journal, 59(4), 1199-1223.

Creed, P. A., \& Hood, M. (2015). The development and initial validation of a scale to assess career goal discrepancies. Journal of Career Assessment, 23(2), 308-317.

Dutton, J. E., \& Ragins, B. R. (2007). Moving Forward: Positive Relationships at Work as a Research Frontier.

Eby, L. T., Allen, T. D., Evans, S. C., Ng, T., \& DuBois, D. L. (2008). Does mentoring matter? A multidisciplinary meta-analysis comparing mentored and non-mentored individuals. Journal of vocational behavior, 72(2), 254-267.

Eby, L. T., Rhodes, J. E., \& Allen, T. D. (2007). Definition and evolution of mentoring. The Blackwell handbook of mentoring: A multiple perspectives approach, 7-20.

Ellis, A. M., Nifadkar, S. S., Bauer, T. N., \& Erdogan, B. (2017). Newcomer adjustment: Examining the role of managers' perception of newcomer proactive behavior during organizational socialization. Journal of Applied Psychology, 102(6), 993. 
Ersoy, N. C., Derous, E., Born, M. P., \& Van der Molen, H. T. (2015). Antecedents of organizational citizenship behavior among Turkish white-collar employees in The Netherlands and Turkey. International Journal of Intercultural Relations, 49, 68-79.

Feeney, B. C., \& Collins, N. L. (2014). A theoretical perspective on the importance of social connections for thriving.

Fletcher, J. K., \& Ragins, B. R. (2007). Stone center relational cultural theory. The handbook of mentoring at work: Theory, research, and practice, 373-399.

Fornell, C., \& Larcker, D. F. (1981). Structural equation models with unobservable variables and measurement error: Algebra and statistics.

Gara Bach Ouerdian, E., \& Mansour, N. (2019). The relationship of social capital with objective career success: the case of Tunisian bankers. The Journal of Management Development, 38(2), 74-86.

Ghosh, R., \& Reio Jr, T. G. (2013). Career benefits associated with mentoring for mentors: A meta-analysis. Journal of Vocational Behavior, 83(1), 106-116.

Godshalk, V. M., \& Sosik, J. J. (2007). Mentoring and leadership. The handbook of mentoring at work: Theory, research, and practice, 149-178.

Götz, O., Liehr-Gobbers, K., \& Krafft, M. (2010). Evaluation of structural equation models using the partial least squares (PLS) approach. In Handbook of partial least squares (pp. 691-711). Springer, Berlin, Heidelberg.

Greenhaus, J. H., Parasuraman, S., \& Wormley, W. M. (1990). Effects of race on organizational experiences, job performance evaluations, and career outcomes. Academy of management Journal, 33(1), 64-86.

Haider, S., Jabeen, S., \& Ahmad, J. (2018). Moderated mediation between work life balance and employee job performance: The role of psychological wellbeing and satisfaction with coworkers. Journal of Work and Organizational Psychology, 34(1), 29-37.

Hair Jr, J. F., Hult, G. T. M., Ringle, C., \& Sarstedt, M. (2016). A primer on partial least squares structural equation modeling (PLS-SEM). Sage publications.

Hair Jr, J. F., Sarstedt, M., Hopkins, L., \& Kuppelwieser, V. G. (2014). Partial least squares structural equation modeling (PLS-SEM): An emerging tool in business research. European business review.

Hair Jr, J. F., Sarstedt, M., Ringle, C. M., \& Gudergan, S. P. (2017). Advanced issues in partial least squares structural equation modeling. saGe publications.

Kahn, W. A. (2007). Meaningful Connections: Positive Relationships and Attachments at Work.

Kram, K. E. (1983). Phases of the mentor relationship. Academy of Management journal, 26(4), 608-625.

Kram, K. E. (1985). Improving the Mentoring Process. Training and Development Journal, 39(4).

Lee, K., \& Allen, N. J. (2002). Organizational citizenship behavior and workplace deviance: The role of affect and cognitions. Journal of applied psychology, 87(1), 131.

Lee, Y., \& Lee, J. Y. (2018). A multilevel analysis of individual and organizational factors that influence the relationship between career development and job-performance improvement. European Journal of Training and Development.

Malik, M. S., \& Nawaz, M. K. Relationship between Mentoring Functions and Career Success with Mediating Role of Career Resilience; Evidence from Pakistani Banking Sector. 43(2), 1201-1221

Motowidlo, S. J. (2003). Job performance. In W. C. Borman, D. R. Ilgen, \& R. J. Klimoski (Eds.), Handbook of psychology: Industrial and organizational psychology, 12 (p. 39-53). John Wiley \& Sons Inc. 
Nabi, G. R. (1999). An investigation into the differential profile of predictors of objective and subjective career success. Career development international.

Niven, K., Holman, D., \& Totterdell, P. (2012). How to win friendship and trust by influencing people's feelings: An investigation of interpersonal affect regulation and the quality of relationships. Human Relations, 65(6), 777-805.

Organ, D. W. (1977). A reappraisal and reinterpretation of the satisfaction-causesperformance hypothesis. Academy of management Review, 2(1), 46-53.

Organ, D. W. (1988). Organizational citizenship behavior: The good soldier syndrome. Lexington Books/DC Heath and Com.

Organ, D. W. (1997). Organizational citizenship behavior: It's construct clean-up time. Human performance, 10(2), 85-97.

Ragins, B. R. (2012). Mentoring.

Ragins, B. R., \& Kram, K. E. (2007). The roots and meaning of mentoring. The handbook of mentoring at work: Theory, research, and practice, 3-15.

Ragins, B. R., \& Verbos, A. K. (2007). Positive relationships in action: Relational mentoring and mentoring schemas in the workplace. Exploring positive relationships at work: Building a theoretical and research foundation, 91-116.

Ramarajan, L., \& Reid, E. (2013). Shattering the myth of separate worlds: Negotiating nonwork identities at work. Academy of Management Review, 38(4), 621-644.

Ringle, C., Da Silva, D., \& Bido, D. (2015). Structural equation modeling with the SmartPLS. Bido, D., da Silva, D., \& Ringle, C.(2014). Structural Equation Modeling with the Smartpls. Brazilian Journal Of Marketing, 13(2).

Rochford, K., Bergeron, D., \& Clerkin, C. (2019). From knowing to doing in workplace relationships: Introducing workplace relational self-efficacy. In Academy of Management Proceedings 1(), p. 12209)

Scandura, T. A. (1992). Mentorship and career mobility: An empirical investigation. Journal of organizational behavior, 13(2), 169-174.

Scandura, T. A., \& Viator, R. E. (1994). Mentoring in public accounting firms: An analysis of mentor-protégé relationships, mentorship functions, and protégé turnover intentions. Accounting, Organizations and Society, 19(8), 717-734.

Shoffner, M. F., Newsome, D., Barrio Minton, C. A., \& Wachter Morris, C. A. (2015). A qualitative exploration of the STEM career-related outcome expectations of young adolescents. Journal of Career Development, 42(2), 102-116.

Somech, A., \& Drach-Zahavy, A. (2000). Understanding extra-role behavior in schools: The relationships between job satisfaction, sense of efficacy, and teachers' extra-role behavior. Teaching and Teacher Education, 16(5-6), 649-659.

Son, S. (2016). Facilitating employee socialization through mentoring relationships. Career Development International.

Spurk, D., Abele, A. E., \& Volmer, J. (2015). The career satisfaction scale in context: A test for measurement invariance across four occupational groups. Journal of Career Assessment, 23(2), 191-209.

Stroebe, W., \& Stroebe, M. (1996). The social psychology of social support.

Tolar, M. H. (2012). Mentoring experiences of high-achieving women. Advances in developing human resources, 14(2), 172-187.

Underhill, C. M. (2006). The effectiveness of mentoring programs in corporate settings: A meta-analytical review of the literature. Journal of vocational behavior, 68(2), 292307.

Van Dierendonck, D., \& van der Gaast, E. (2013). Goal orientation, academic competences and early career success. Career Development International. 
Muhammad Shaukat Malik, Muhammad Kashif Nawaz

Williams, L. J., \& Anderson, S. E. (1991). Job satisfaction and organizational commitment as predictors of organizational citizenship and in-role behaviors. Journal of management, 17(3), 601-617. 